\title{
Cereal straw management: a trade-off between energy and agronomic fate
}

\author{
Massimo Monteleone, Pasquale Garofalo, Anna Rita Bernadette Cammerino, \\ Angela Libutti
}

\author{
STAR *AgroEnergy Research Group, Department of Agriculture, Food and Environment, \\ University of Foggia, Italy
}

\begin{abstract}
Climate change mitigation is the most important driving force for bioenergy development. Consequently, the environmental design of bioenergy value chains should address the actual savings of both primary energy demand and greenhouse gases (GHG) emissions. According to the EU Renewable Energy Directive (2009/28/EC), no direct impacts and no GHG emissions should be attributed to crop residues (like cereal straws) when they are removed from agricultural land for the purpose of bioenergy utilisation. The carbon neutral assumption applied to crop residues is, however, a rough simplification. Crop residues, indeed, should not be viewed simply as a waste to be disposed, because they play a critical role in sustaining soil organic matter and therefore have an inherent $\mathrm{C}$-capturing value. Moreover, considering straws as an energy feedstock, its status of co-product is clearly recognised and its availability could be obtained according to different cropping systems, corresponding to different primary energy costs and GHG emissions. This paper highlights some hidden features in the assessment of agricultural energy and carbon balance, still very
\end{abstract}

\footnotetext{
Correspondence: Massimo Monteleone, Department of Agriculture, Food and Environment, University of Foggia, via Napoli 25, 71121 Foggia, Italy.

E-mail: massimo.monteleone@unifg.it
}

Key words: Life cycle assessment; soil organic carbon; greenhouse gases; emission abatement; $\mathrm{N}_{2} \mathrm{O}$ soil emissions; land use change; agroenergy farming.

Acknowledgements: the authors are very grateful to the STAR*AgroEnergy Project of the University of Foggia, funded by the European Commission, Seventh Framework Programme (FP7), Regpot 2011-1. Grant Agreement $N^{\circ}$ 286269. STAR*AgroEnergy (Strategic \& Technological Advancement in Research on AgroEnergy) promotes an integrated approach to renewable energy generation and knowledge based bio-economy, according to sustainability criteria.

Conference presentation: SIA XLIII Congress, Pisa, 2014.

Received for publication: 29 January 2015.

Revision received: 11 April 2015

Accepted for publication: 18 April 2015.

(C) Copyright M. Monteleone et al., 2015

Licensee PAGEPress, Italy

Italian Journal of Agronomy 2015; 10:655

doi:10.4081/ija.2015.655

This article is distributed under the terms of the Creative Commons Attribution Noncommercial License (by-nc 3.0) which permits any noncommercial use, distribution, and reproduction in any medium, provided the original author(s) and source are credited. difficult to be detected and accounted for. Although they are frequently disregarded, these features (such as long term dynamic trend of soil organic carbon and annual nitrous oxide emissions from the soil) should be carefully considered in assembling the energy and emission balance. By using a crop simulation model, the long-term soil organic matter and annual $\mathrm{N}_{2} \mathrm{O}$ soil emissions were estimated. Consequently, a comprehensive energy and GHG balance was determined in accordance with the life cycle assessment methodology. Contrasting methods of straw management and wheat cultivation were compared: straw retention vs removal from the soil; conventional vs conservation tillage; wheat cropping system as a single-crop or in rotation. The resulting carbon footprint of straws has different magnitudes with respect to the several experimental conditions. By selecting the best agricultural practices, energy from straw can be optimally coupled with grain productions, without detrimental effects on soil fertility. An improved and specifically tailored cropping system is designed to obtain an optimal trade-off.

\section{Introduction}

The potentials of climate-change mitigation associated with bioenergy arise from biomass ability to displace the use of fossil fuels and so exhibit theoretical carbon neutral conditions. Carbon neutrality means achieving net zero carbon emissions by balancing a measured amount of carbon released with a corresponding amount been offset or sequestered. Of course, when talking about carbon we are also considering including the other greenhouse gases (GHG), properly converted into their carbon dioxide equivalence $\left(\mathrm{CO}_{2}-\mathrm{e}\right)$.

When applied to biomass and bioenergy, the concept of carbon neutrality states that the total amount of $\mathrm{CO}_{2}$ absorbed from the atmosphere and assimilated into new organic compounds through crop growth is the same amount of $\mathrm{CO}_{2}$ released back into the atmosphere because of biomass-to-energy conversion. However, this neutrality can be achieved only partially, because every energy cost associated to biomass utilisation (collecting, transportation, storage, conditioning, etc.) represents a decrease in the energy return of the process and a positive emission of $\mathrm{CO}_{2}$ equivalents. In order to contribute effectively to global warming mitigation, every bioenergy value chain (with respect to its specific form of energy end-product) should provide a large energy gain (positive $\Delta \mathrm{E}$ ) and a significant net carbon savings (negative $\Delta \mathrm{GHG}$ ) compared to the corresponding fossil fuel chain.

These strict environmental criteria are not unique to bioenergy, but should be extended to any type of production process and, above all, should apply to primary production. Agriculture, indeed, should rely mostly on the radiant energy coming from the sun and relieve itself from fossil dependency as much as possible (Monteleone, 2015). Therefore, improving the use efficiency of energy and resource inputs, as well as reducing GHG emissions, are fundamental targets to reach sustainable agricultural performance. These concepts are key issues 
applied both to agro-food and agro-energy value chains. The strategic priority assigned to food is relevant but we also need to understand that food and energy are strictly interlinked, and it is difficult to provide food without having energy. Therefore, the greater the fossils replaced and the GHG emissions saved, the higher the sustainability level achieved along the entire productive chain. Biomass supply may arise directly, i.e., from dedicated energy crops, or indirectly, i.e., from crop residues and agro-food wastes. The so-called first generation fuels are obtained from the former, while the second-generation fuels from the latter. The major change between these two forms of biomass supply concerns the allocation of the energy costs of farming, that are charged totally to the management of the dedicated energy crops and only partially (or not at all) to that of crop residues (because assigned to the corresponding main-product).

The EU Renewable Energy Directive (2009/28/EC), commonly called RED, has defined the framework for the promotion of energy from renewable sources. The target is to achieve a $20 \%$ share of energies from renewables, reduce of $20 \%$ GHG emissions and reach a $10 \%$ of renewables in the transport sector by 2020 . The same Directive also gave a first, still incomplete, set of sustainability requirements biofuels should comply with regard to the feedstock to be used in bioenergy conversion processes. The RED was released after two years of intense public and political debate. This debate is still very much alive and opinions on the usefulness of biomass as an energy source alternative to fossils are still controversial. On this respect, biofuels have been deemed to be almost environmentally useless or even worse than fossils in accelerating climate change and responsible for food insecurity and the volatility of market prices (Fargione et al., 2008; Searchinger $e t$ al., 2008; Davis et al., 2009; Gnansounou et al., 2009). Therefore, it is increasingly important to distinguish bioenergy options that can address energy security and greenhouse gas mitigation from those that cannot (Dale et al., 2010; Davis et al., 2011).

First generation biofuels might cause a direct competition between food and fuel (or even feed and fuel), boost the pressure on land use, raise the intensity of farming and generate the risk of an increase (rather than a decrease) of climate-altering emissions. Conversely, second generation biofuels are supposed not to be in direct competition with food crops and might represent an additional biomass resource to be exploited, without shifting the final food destination of the main product. This strategy could increase the energy efficiency of the entire process, according to a cascading biomass utilisation approach (Odegard et al., 2012; Keegan et al., 2013). Accordingly, in order to give second generation biofuels a public support, the RED states that these biofuels should receive a double energy credit in reaching the national targets (RED, article $21 \S 2$ ), and the feedstock from which they are obtained are considered available at zero GHG costs (Whittaker and McManus, 2012). In other words, according with the RED, there are no direct impacts from residue removal and no emissions or energy consumptions should be attributed to cereal residues when they are removed from agricultural land with the purpose of energy utilisation. The interpretation of this decision relies on the fact that crop residues are not considered co-products but, in general terms, are more similar to waste; as a consequence, following the specific life cycle assessment (LCA) terminology, no allocation criteria are applied in splitting the cereal environmental burden between grain (the main product) and straw (the residues).

A recent EU development, COM(2012) 595, still an amending proposal to the RED, states that with respect to feedstock like straw, animal manure, sewage sludge, bagasse, nut shells, husks, etc. their energy contribution shall be considered to be four times their actual energy content. This new EU regulatory framework is going to generate a great interest on straw as an energy feedstock, diverting from its conventional use both in animal-bedding and agricultural return to soil.
This assumption of zero emission by crop residues, as the RED is stating, should be considered an incorrect or, at least, a very rough simplification. As any agricultural technician or practitioner already knows very well, crop residues should not be perceived as a waste because they play a critical role in sustaining soil organic matter (Cowie et al., 2006; Lal, 2008). This means that they have an intrinsic value also in term of $\mathrm{CO}_{2}$ capture and consequent storage into the soil (Kumar and Goh, 2000). Removing straws may negatively affect soil fertility and its productivity with respect to nutrient recycling, $\mathrm{N}_{2} \mathrm{O}$ emissions from the soil, soil-amending properties, soil erosion control, and several other soil physical, chemical and microbiological characteristics (Cherubini and Ulgiati, 2010; Whittaker and McManus, 2012). Moreover, the amount of available crop residues and their effects on soil are affected strongly by local conditions, such as climate, soil type, crop management (Lal, 2008; Cherubini and Ulgiati, 2010). In particular, the environments with Mediterranean climate conditions generally are characterised by low levels of soil organic matter; in these cases, the retention of straw into the soil (or on the top of it) may have a vital positive effect. All these considered effects associated to straw removal are able to generate further carbon (equivalent) emissions into the atmosphere, thus generating extra carbon debts that should be accounted for in compiling the total budget.

LCA is the methodology usually applied to perform the carbon and GHG budgets; a specific approach applied as testing procedures on biofuels and bioenergy carriers was developed (Cherubini et al., 2009; Cherubini, 2010).

Based on the above considerations, it can be stated that some hidden (although significant) features in the agricultural LCA are still very difficult to detect; for this reason, they are frequently disregarded. These kinds of side effects (or hidden factors) have determined a new research issue in the assessment of bioenergy sustainability. This issue considers the effects of direct land use changes (dLUC) in consequence of different forms of agricultural management and the resulting impact in terms of energy costs and emissions budget (Berndes et $a l ., 2010$ ). These impacts could be either negative (i.e., increasing GHG emissions and decreasing energy gain) or positive (the reverse effect), according to specific conditions. An indirect land use change (iLUC) might also appear in case a higher level of biomass exploitation gives rise to a local shrinkage of land surfaces under food-crop cultivation: in this case, the previous availability of food supply should be fulfilled by other cropping areas inside or outside the region (Gnansounou et al., 2008; Fritsche et al., 2010).

This study aims to explore and provide an estimate of these hidden factors, addressing a complete energy balance and a net GHG emission budget, according to a LCA approach. Using a previously calibrated and validated crop-system simulation model (Donatelli et al., 1997; Garofalo et al., 2009), an attempt to estimate the long-term fate of soil organic carbon (SOC), together with the cumulative annual soil $\mathrm{N}_{2} \mathrm{O}$ emissions was performed. Contrasting methods of straw management and wheat cultivation were compared: straw retention $v s$ removal from the soil; conventional $v s$ conservation tillage; wheat cropping system as a single-crop $v s$ crop rotation. The reference cropping system (the one considered conventional in the region) is a single-wheat cultivation whose straws, properly shredded, are left behind the harvesting machine at the top of the soil. An alternative straw destination is the biomass-toenergy conversion process. The cropping system is modified in its management in order to consider straw collection and baling, but without any other significant changes of the former cropping system. An unusual and improved wheat cropping system is ultimately compared with the former two. In this latter case, conservation tillage is applied on a rotated wheat cultivation system, partially addressing straw both to soil and to energy.

This paper is mostly focused on the assessment of processes worked 
out at the field and farm level, but also considers the energy feedstock in the subsequent harvesting, bailing and transportation stages, as well as the final thermochemical process of combustion followed by a steam-turbine power generation. The optimal, i.e., the best performing system is selected and commented in terms of sustainability criteria, the same criteria the RED has indicated as the most influential.

\section{Materials and methods}

\section{Cropping system scenarios}

The wheat cropping system was the productive system under analysis. The straws resulting from wheat cultivation could be left on the soil in order to restore mineral nutrients and preserve soil fertility in its organic matter. Alternatively to soil retention, straws can be addressed to energy conversion; in this case, a quite large combustion power plant ( $25 \mathrm{MWe}$ ), located at the centre of a wide cereal basins in the province of Foggia (Southern Italy), is assumed to be supplied by the available straws. More specifically, three wheat cultivation systems have been assumed and compared:

- W0. Wheat is cultivated according to the conventional cropping system for the region, namely through seedbed preparation by ordinary ploughing. Moreover, wheat is cultivated farm-wide each year, therefore without any form of rotation (single-crop farming). Crop residues (straws), after harvesting, are left on the soil surface properly shredded. WO should be considered as the reference system, or baseline, whose focus is on the agro-ecological valorisation of crop residues.

- W1. As in the previous system, wheat is cultivated according to the conventional cropping system for the region and as a single-crop. Differently from $W 0$, however, straws are removed from the field in order to supply a bioenergy value chain. Beside grain production, this system should be considered mainly focused on the energy valorisation of crop residues.

- W2. Wheat is cultivated according to a conservation tillage system (quite unusual in the region), namely through alternative soil operations with respect to ploughing and, more specifically, following a no-tillage practice. Differently from $W 0$ and $W 1$, wheat is cultivated on $2 / 3$ of the farm surface, therefore in rotation (one year out of three) with a winter herbage (triticale). Once harvested, half of the herbage is left over the soil surface (herbal mulching) and the other half is addressed to energy generation. This system should be considered as an innovative wheat cultivation system, mainly focused on reconciling the energy valorisation of straws with their agro-ecological service.

Wheat was assumed to be cultivated following the crop management system usually applied in the Mediterranean area of the Foggia province, with respect both to mechanical operations and agro-chemicals applications. The difference between conventional- and no-tillage is related to simplified soil mechanical operations that consisted in a direct sowing in the latter case as compared to three consecutive harrowing after the principal ploughing in the former case.

The assumed average grain yield is $3 \mathrm{Mg} \mathrm{ha}^{-1}$ with a corresponding unitary average harvest index (grain/straw ratio=1). On average, the amount of straws that is effectively collected is $1.2 \mathrm{Mg} \mathrm{ha}^{-1}$ (on dry basis), with biomass at $15 \%$ of humidity. The straws left on the soil add up to $1.4 \mathrm{Mg} \mathrm{ha}^{-1}$. Therefore, $0.4 \mathrm{Mg} \mathrm{ha}^{-1}$ is the amount of the off-farm straw losses. The herbage of triticale is cultivated similarly to wheat but mowed much earlier, at the dough development stage of the kernel, approximately 20-25 days after flowering. The herbage yield amounts to approximately $10 \mathrm{Mg} \mathrm{ha}^{-1}$ (on dry basis) with biomass at about $70 \%$ of humidity: $4.8 \mathrm{Mg} \mathrm{ha}^{-1}$ is the biomass exported and $4.1 \mathrm{Mg} \mathrm{ha}^{-1}$ is the biomass left on the soil. Fertilising nitrogen (N) and phosphorus $\left(\mathrm{P}_{2} \mathrm{O}_{5}\right)$ were applied at rates of 120 and $100 \mathrm{~kg} \mathrm{ha}^{-1}$, respectively.

\section{Life cycle assessment}

Since secure energy supply and climate change mitigation are the main drivers in searching for renewable alternatives to fossils, the application of LCA in this work was focused on the calculation of the net energy budget (accounting for fossils displacement after subtracting the energy costs incurred) and on the corresponding GHG emissions saved (Cherubini and Ulgiati, 2010). No other environmental impact categories have been estimated in this study.

A consequential LCA (C-LCA) was applied (conveniently employing the calculation tool from BioGrace, 2014), providing information about the consequences due to changes that may occur in the productive process, including effects both inside and outside the considered system (Brander et al., 2009). C-LCA was considered a proper approach in order to account for the effects originating from land use changes. The technical advice to move from the ordinary productive system $(W 0)$ to a modified (W1) or an improved cropping system (W2) seeks to inform decision makers about the lower environmental impacts that could be consequently obtained.

The functional units that were considered in conducting LCA were both the agricultural land unit (hectare - $h a$ ) and the energy unit (one $M W h$ ), in order to properly account for the effects on both the land use change and the energy efficiency performed by the compared systems.

Energy analysis has considered all forms of auxiliary fossil energy inputs, accurately traced according to a physical inventory of material flows (Alluvione et al., 2011). After a proper quantification, these material flows were transformed into energy flows, applying specific energy equivalents. The coefficients reported in the RED and those used in the EU BioGrace Project (2014) have been applied. This choice aims to harmonise calculations of energy balance and greenhouse gas emissions from biomass throughout the European Union. Direct energy inputs refer to the energy content of fuels and lubricants (no electrical power was used in cropping operations). Indirect energy inputs considered the amount of energy spent for the production, transportation and maintenance of all agro-technical inputs. Some of these inputs are completely consumed in the course of the cropping cycle (such as fertilisers, irrigation water, herbicides and pesticides, etc.) while others are only gradually employed (like tractors, machines and all kind of implements) and their partial energy consumption (or energy amortisation) should be carefully determined with respect to their productive life horizon. Energy inputs were therefore divided into three clusters: i) mechanisation, which includes tractors and other implements or equipment; ii) fuels and lubricants; iii) other agro-technical inputs.

The same conceptual approach was used to assess the GHG emissions, once more referring to the EU BioGrace Project (2014) and the set of available conversion coefficients.

\section{Direct and indirect land use changes}

As already stated, the reference land use considered in this analysis is agricultural land where wheat straw is left on the field (WO). Following Cherubini and Ulgiati (2010), when these residues are collected and used as energy feedstock (as in the $W 1$ or $W 2$ systems), the main GHG implications in comparison with the reference land use ( $W 0$, in the case of this work) are factors related to dLUC, such as:

- Change in SOC. A decreasing SOC lead to a loss in carbon stocks with $\mathrm{C}$ released as $\mathrm{CO}_{2}$, thus increasing $\mathrm{GHG}$ emissions.

- Change in crop grain yield, i.e., a reduction because of a lower mineralisation of $\mathrm{N}$ in soil (together with $\mathrm{P}$ and $\mathrm{K}$ ). This would require a corresponding increase of synthetic fertiliser to be applied to com- 
pensate the nutrients removed with the straws (Gabrielle and Gagnaire, 2008). A higher supply of fertiliser implies higher energy costs and GHG emissions.

- Change in $\mathrm{N}_{2} \mathrm{O}$ emissions from the cultivated soil. The amount of $\mathrm{N}_{2} \mathrm{O}$ released from the soil is related to the amount of $\mathrm{N}$ fertiliser applied, but several other factors have a relevant influence on this process. It is observed that generally increasing straw removal favours a decrease in $\mathrm{N}_{2} \mathrm{O}$ emissions. This could be interpreted since straw return to soil increases soil denitrification potentials and its capacity to produce $\mathrm{N}_{2} \mathrm{O}$ (Cai et al., 2001). This means that the additional and compensating fertilisers amount related to the previous point enhances $\mathrm{N}_{2} \mathrm{O}$ soil emissions at a lower rate than straw incorporation into the soil (Cherubini and Ulgiati, 2010).

Apart from those factors, there are other relevant factors in the analysed case study able to alter significantly the energy budget and the amount of GHG emissions; these factors are related to iLUC. Considering the wheat system $W 2$ with respect to $W 1$, it is possible to detect a change in the total surface of agricultural land needed in supplying the same biomass energy plant. As for the $W 2$ rotation systems, the average available biomass is $2.4 \mathrm{Mg} \mathrm{ha}^{-1}$ (2/3 wheat and 1/3 triticale) while in the $W 1$ single-wheat cropping system the available biomass is $1.2 \mathrm{Mg} \mathrm{ha}^{-1}$. Considering that biomass availability per unit of land surface is approximately the double in $W 2$ with respect to $W 1$, it follows that the total land surface of the biomass supply basin is about the half. Let see below what are the consequences of this relevant decrease in agricultural land surface due to crop rotation:

- The same amount of electrical energy is obtained from half the surface previously needed. This implies (ceteris paribus) to gain an energy cost per unit of generated electricity halved in W2 as compared with $W 1$. Exactly the same $50 \%$ reduction is obtained considering the amount of $\mathrm{CO}_{2}$ emitted per unit of generated electricity.

Concentrating biomass availability (i.e., achieving a higher biomass land density) has another relevant effect in reducing biomass transportation costs. According to our GIS calculations, specifically related to the case study of the Foggia province, to halve the extent of the biomass supply basin means to reduce the total energy and the associated emission costs due to biomass hauling at approximately $40 \%$.

The last factor that is worth to be accounted for is, this time, a negative effect, since it involves an increase in energy costs and GHG emissions allocated to the innovative cropping system $W 2$ with respect to $W 1$. Given that the agricultural land reserved to wheat grain production was reduced by $1 / 3$ moving from system W0 or W1 to system W2, it also follows that the grain productivity was decreased of the same amount. In order to perform a homogeneous comparison between the systems, the total energy costs and GHG emissions allocated to wheat cultivation (properly weighted by $1 / 3$ ) should be assigned as a debt to the $W 2$ system. In this way, the reduced grain productivity of W2 is compensated perfectly and the missing cereal production could be considered produced somewhere else (but in the same technical conditions).

\section{Long term simulation of wheat cropping system}

Alternative uses or straw (removed or left on the soil), alternative tillage systems (conventional $v s$ conservation techniques), alternative cropping systems (single crop $v s$ crop rotation) may lead to a significant change in the amount of the stored SOC along the first $0.30 \mathrm{~m}$ of the soil profile. This is the soil depth assumed to be reached by ploughing, thus periodically disturbed in the conventional tillage with respect to the conservation system. It is worth to mention that the annual SOC change rate was determined as the average annual value with respect to the overall difference estimated in the 50 -y period. Generally, these changes in SOC content are not taken into account in the GHG balance of bioenergy systems (Cherubini and Ulgiati, 2010), unless few excep- tions (Jungmeier and Schwaiger, 2000).

In order to quantify properly the long-term amount of SOC, the cropping system simulation model CropSyst (Stöckle et al., 2003) was used. CropSyst is a multi-year, multi-crop, daily time-step simulation model, designed to serve as an analytical tool to assess the effects of management and environmental conditions on crops performance. Seasonal cropping cycles over a consecutive 50-y period (1960-2010) were performed applying the actual meteorological data recorded in Foggia (Southern Italy). A starting SOC value equal to $1.2 \%$ was assumed, thus interpreting a rather common condition of Mediterranean soils, often characterised by a summer semi-arid kind of climate. Previous works allowed a proper calibration and validation of the model, specifically on wheat cultivation systems in Southern Italy environmental conditions (Garofalo et al., 2009). Generally, the model showed a good performance as compared to experimental data after a parameters' calibration set. CropSyst is able to simulate a very wide range of processes (according to several environmental and management conditions) such as soil-water balance, soil-plant nitrogen budget, canopy cover and root growth, crop phenology, total biomass production, crop yield, management of crop residues left on the soil and their decomposition, soil organic matter and soil carbon stock, soil erosion, etc. Considering that the majority of the processes are very site-specific and highly dependent on agronomic practices, climate and soil characteristics, the great complexity of the interlinked processes and the long period of analysis, the use of a simulation model is almost essential (Meki et al., 2014).

A specific output of the model is the amount of $\mathrm{N}_{2} \mathrm{O}$ released in form of emission from the soil. $\mathrm{N}_{2} \mathrm{O}$ emissions could be associated to both nitrification and denitrification microbiological processes, consequent to different soil characteristics and conditions (Venterea et al., 2012; Butterbach-Bahl et al., 2013). The absence of a previous experimental data-set did not allowed to assess the actual reliability of the simulations with respect to $\mathrm{N}_{2} \mathrm{O}$ emissions, but simply to check their consistency with results obtained from similar works by other Authors (Gabrielle and Gagnaire, 2008; Gan et al., 2012).

\section{Results and discussion}

Table 1 shows the energy costs of wheat cultivation systems, considering both conventional and conservation tillage. As expected, conventional cropping system showed higher total energy expenditure (14.6 $\mathrm{GJ} \mathrm{ha}^{-1}$ ) compared with conservation system (12.2 $\left.\mathrm{GJ} \mathrm{ha}^{-1}\right)$. In relative terms, a higher energy allocation to diesel and lubricants (33.6 vs 20.6\%) was observed in the former than the latter. Fertiliser, pesticides and seeds (i.e., materials) showed the highest energy contribution in both the systems ( 63.3 and $77.5 \%$ for conventional and conservation systems, respectively).

Concerning GHG emission, Table 2 shows the amount of $\mathrm{CO}_{2}$ equivalents that should be allocated to the two systems, i.e., conventional and conservation systems, respectively. Again, the wheat cropping system based on conventional tillage was characterised by higher total GHG emissions (1.38 $\mathrm{Mg} \mathrm{ha}^{-1}$ ) as compared with the conservation system $\left(1.19 \mathrm{Mg} \mathrm{ha}^{-1}\right)$. This was due to a higher relative emission contribution from diesel in the first system (31\%) than in the second (18\%). Conversely, a contribution of 55 and $64 \%$ of the total GHG emissions was accounted for by $\mathrm{N}$ fertilisation, in the conventional and conservation systems, respectively. Therefore, in our case study, $\mathrm{N}$ fertilisation represented the highest emission factor among the agro-technical inputs in wheat cultivation.

We turn now to compare the three wheat-cropping systems ( $W 0, W 1$ and W2) with respect to net energy budget and net GHG emissions.

Table 3 reports the energy budget of the three systems. From the 
Table 1. Energy inputs applied to wheat farming, considering the implementation of conventional tillage or, alternatively, conservation tillage. All the values are expressed in $\mathrm{MJ} \mathrm{ha}^{-1}$.

\begin{tabular}{|c|c|c|c|c|}
\hline Operations & Diesel and lubricants & Tractors and machinery & Materials & Total \\
\hline \multicolumn{5}{|c|}{ Conventional tillage } \\
\hline Ploughing & 1193.01 & 108.74 & - & 1301.74 \\
\hline Harrowing (I+II+III) & 1303.27 & 132.54 & - & 1435.81 \\
\hline Fertiliser prepar./transp. & 144.29 & 18.78 & - & 163.08 \\
\hline Basal dressing & 144.29 & 10.41 & 3165.13 & 3319.84 \\
\hline Seed prepar.transp. & 144.29 & 18.78 & - & 163.08 \\
\hline Sowing & 380.94 & 43.54 & 909.15 & 1333.63 \\
\hline Fertiliser prepar./transp. & 144.29 & 18.78 & - & 163.08 \\
\hline Top dressing & 144.29 & 10.41 & 4507.14 & 4661.84 \\
\hline Herbicide application & 144.29 & 11.60 & 671.00 & 826.90 \\
\hline Combined harvesting & 1171.31 & 80.39 & - & 1251.70 \\
\hline Total & 4914.29 & 453.97 & 9252.41 & $14,620.68$ \\
\hline Partitioning (\%) & 33.61 & 3.10 & 63.28 & 100.00 \\
\hline \multicolumn{5}{|c|}{ Conservation tillage } \\
\hline Fertiliser prepar./transp. & 144.29 & 18.78 & - & 163.08 \\
\hline Basal dressing & 144.29 & 10.41 & 3165.13 & 3319.84 \\
\hline Seed prepar.transp. & 144.29 & 18.78 & - & 163.08 \\
\hline Sowing & 476.17 & 61.01 & 1090.97 & 1628.15 \\
\hline Fertiliser prepar/transp. & 144.29 & 18.78 & - & 163.08 \\
\hline Top dressing & 144.29 & 10.41 & 4507.14 & 4661.84 \\
\hline Herbicide application & 144.29 & 11.60 & 671.00 & 826.90 \\
\hline Combined harvesting & 1171.31 & 80.39 & - & 1251.70 \\
\hline Total & 2513.25 & 230.15 & 9434.24 & $12,177.65$ \\
\hline Partitioning (\%) & 20.64 & 1.89 & 77.47 & 100.00 \\
\hline
\end{tabular}

Table 2. Greenhouse gases emissions associated to wheat farming, considering the implementation of conventional tillage or, alternatively, conservation tillage.

\begin{tabular}{|c|c|c|c|c|}
\hline Agricultural inputs & $\begin{array}{l}\text { GHG coefficients } \\
\text { (g CO } \mathrm{CO}_{2} \text {-eq/kg) }\end{array}$ & $\begin{array}{l}\text { Amount } \\
\text { (kg/ha) }\end{array}$ & $\begin{array}{l}\text { GHG emissions } \\
\text { (kg CO }{ }_{2} \text {-eq/ha) }\end{array}$ & $\begin{array}{c}\text { Partitioning } \\
(\%)\end{array}$ \\
\hline \multicolumn{5}{|c|}{ Conventional tillage } \\
\hline N-fertiliser & 5917.231 & 128.000 & 757.406 & 54.94 \\
\hline $\mathrm{P}_{2} \mathrm{O}_{5}$ fertiliser & 1013.509 & 92.000 & 93.243 & 6.76 \\
\hline $\mathrm{K}_{2} \mathrm{O}$ fertiliser & 579.249 & 0.000 & 0.000 & 0.00 \\
\hline Pesticides & $11,025.737$ & 3.750 & 41.347 & 3.00 \\
\hline Seeds & 277.273 & 220.000 & 61.000 & 4.42 \\
\hline Diesel & 3777.284 & 112.354 & 424.393 & 30.78 \\
\hline Lubricants & 947.000 & 1.348 & 1.277 & 0.09 \\
\hline Total & - & - & 1378.665 & 100.00 \\
\hline \multicolumn{5}{|c|}{ Conservation tillage } \\
\hline $\mathrm{N}$-fertiliser & 5917.231 & 128.000 & 757.406 & 63.88 \\
\hline $\mathrm{P}_{2} \mathrm{O}_{5}$ fertiliser & 1013.509 & 92.000 & 93.243 & 7.86 \\
\hline $\mathrm{K}_{2} \mathrm{O}$ fertiliser & 579.249 & 0.000 & 0.000 & 0.00 \\
\hline Pesticides & $11,025.737$ & 4.000 & 44.103 & 3.72 \\
\hline Seeds & 277.273 & 264.000 & 73.200 & 6.17 \\
\hline Diesel & 3777.284 & 57.460 & 217.042 & 18.31 \\
\hline Lubricants & 947.000 & 0.690 & 0.653 & 0.06 \\
\hline Total & - & - & 1185.646 & 100.00 \\
\hline
\end{tabular}

GHG, greenhouse gases. 
table, it is clear that when straws are addressed to energy conversion they can contribute significantly to fossil displacement and largely compensate the increased energy required along the post farm stages (including straw baling and bale transportation) as well as the compensation effects associated to land use changes consequent to the diversion of straws from the soil. Straw removal in a single-crop system (W1) allowed a net energy gain (at the energy plant gates) of approximately $5.5 \mathrm{GJ} \mathrm{ha}^{-1}$ compared to $W 0$, while straw removal combined with crop rotation (W2) further improved this net energy gain to $9.7 \mathrm{GJ} \mathrm{ha}^{-1}$. Reducing tillage operations and introducing a conservation tillage system, allowed a quite large energy saving of approximately $2.4 \mathrm{GJ} \mathrm{ha}^{-1}$ (W1 vs W2 difference just considering the farm stage). A very strong energy penalty ( $4.1 \mathrm{GJ} \mathrm{ha}^{-1}$ ) was attributed to $\mathrm{W} 2$ to compensate the reduction in cereal yield due to the insertion of a herbage-crop in rotation with wheat, one year out of three. Although considering this relevant energy cost, the higher biomass spatial concentration consequent to crop rotation significantly increased the total energy credit, from 6.0 (in W1) to $11.9 \mathrm{GJ} \mathrm{ha}^{-1}$ (in W2). It is worth to note that the energy involved in straw transportation was very low (49.2 $\mathrm{MJ} \mathrm{ha}^{-1}$ ) if compared to baling, and one order of magnitude lower than the latter (400.3 MJ ha-1).

Table 4 reports the GHG emission values. The first three-column set of Table 4 is referring to the agricultural land surface unit (ha). W1 showed better results as compared with $W 0$, while $W 2$ was even better with respect to $W 1$. Considering the hectare as the functional unit of reference, $0.4 \mathrm{Mg} \mathrm{ha}^{-1}$ of $\mathrm{CO}_{2}$-eq. were totally saved in $W 1$ while almost $1.1 \mathrm{Mg} \mathrm{ha}^{-1}$ were avoided in $W 2$ (in both cases in comparison to W0).

A different soil tillage management (from conventional to conservation tillage) resulted in $0.19 \mathrm{Mg} \mathrm{ha}^{-1}$ of $\mathrm{CO}_{2}$ eq. for the benefit of $W 2$.

The effect of straw management and crop rotation can be clearly detected considering the changes in the SOC content as outline below: i) straw left on the soil (WO) increased the soil organic matter, determining an average annual carbon credit of $0.37 \mathrm{Mg} \mathrm{ha}^{-1} \mathrm{y}^{-1}$; ii) a systematic straw removal under single crop cultivation (W1) produced an average annual carbon debt of $0.15 \mathrm{Mg} \mathrm{ha}^{-1} \mathrm{y}^{-1}$; iii) straw removal coupled with a partial herbage mulching (W2) restored the soil carbon credit conditions (an annual average $0.10 \mathrm{Mg} \mathrm{ha}^{-1} \mathrm{y}^{-1}$ was observed), proving to be very effective in preserving soil organic matter.

$\mathrm{N}_{2} \mathrm{O}$ released from the soil had an influential effect on $\mathrm{GHG}$ budget. The amount of these $\mathrm{CO}_{2}$ equivalent losses were substantially in accordance with that reported by other Authors (Gabrielle and Gagnaire, 2008; Gan et al., 2012) and clearly showed that straws retention on the soil played the effect to enhance $\mathrm{N}_{2} \mathrm{O}$ emissions. Therefore, the highest carbon debts $\left(0.45 \mathrm{Mg} \mathrm{ha}^{-1} \mathrm{y}^{-1}\right)$ was assigned to $W 0$ (systematic straw retention), while to $W 1$ (systematic straw removal) the lowest $(0.26 \mathrm{Mg}$ $\left.\mathrm{ha}^{-1} \mathrm{y}^{-1}\right)$; close to $W 0$, but a little bit lower $\left(0.41 \mathrm{Mg} \mathrm{ha}^{-1} \mathrm{y}^{-1}\right)$ the carbon debt showed by $W 2$ (systematic straw removal but with a partial herbage mulching). Comparable to the amount of carbon equivalents assigned to $\mathrm{N}_{2} \mathrm{O}$ is the carbon debt allotted to $W 2$ to compensate for the reduced grain yield due to crop rotation $\left(0.40 \mathrm{Mg} \mathrm{ha}^{-1} \mathrm{y}^{-1}\right)$. Quite low (in both $W 1$ and $W 2$ ) was the compensation of the carbon debt due to the straw fertilising value ( 0.04 and $0.03 \mathrm{Mg} \mathrm{ha}^{-1} \mathrm{y}^{-1}$, respectively). Still considering Table 4, but this time referring to the second three-column set, the values of the avoided GHG emissions per unit of electrical energy production (MWh) are reported. Even larger effects were detected compared to the hectare as functional unit. In this case, 0.24 and 0.76 $\mathrm{Mg} \mathrm{MWh}^{-1} \mathrm{y}^{-1}$ were the amount of $\mathrm{CO}_{2}$ eq saved in $W 1$ and $W 2$ respectively. The largest amount of carbon saved $\left(0.46 \mathrm{Mg} \mathrm{MWh}^{-1} \mathrm{y}^{-1}\right)$ was detected at the farming stage, due to the combined effects of two factors: i) the reduced mechanisation due to change in tillage system (from conventional to conservation tillage); and ii) the reduced land surface assigned to wheat cultivation when the innovative cropping system was applied (shifting from single-wheat to crop rotation).

This equivalent carbon amount is approximately the same of that quantifying the carbon credit obtained from the power conversion of straws to generate electricity (due to fossils displacement). The emissions annually saved in $W 2$ as compared with $W 1$ are very relevant;

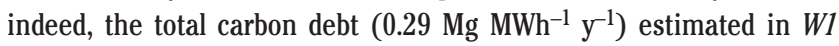
turned out to be a negative and not a positive term $\left(-0.23 \mathrm{Mg} \mathrm{MWh}^{-1}\right)$ considering $W 2$.

Table 3. Energy inputs applied to the three wheat (grain and straw) value chains (W1, W2 and W3 as specified in the text).

\begin{tabular}{|c|c|c|c|}
\hline \multirow[t]{2}{*}{ Production stages } & \multicolumn{3}{|c|}{ Energy budget (MJ/ha ) } \\
\hline & WO & W1 & W2 \\
\hline \multicolumn{4}{|l|}{ Farm stage } \\
\hline Wheat cultivation & $14,620.68$ & $14,620.68$ & $12,177.65$ \\
\hline Delta due to the farming stage & - & - & -2568.20 \\
\hline Straw chopping & 125.17 & - & - \\
\hline Compensation of the straw fertilising value & - & 383.69 & 255.79 \\
\hline Compensation for reduced grain due to crop rotation & - & - & 4059.22 \\
\hline Delta due to land use change & 125.17 & 383.69 & 4315.01 \\
\hline \multicolumn{4}{|l|}{ Post farm stage } \\
\hline Straw baling & - & 200.16 & 400.31 \\
\hline Transportation & - & 67.92 & 49.16 \\
\hline Delta due to post farm stage & - & 468.23 & 449.47 \\
\hline Energy debts (sum of the delta values) & 125.17 & 526.59 & 2196.28 \\
\hline Energy credits (fossil displacement) & - & -6033.31 & $-11,934.75$ \\
\hline Total balance & 125.170 & -5506.72 & -9738.47 \\
\hline Delta with respect to $W 0$ & - & -5631.89 & -9863.64 \\
\hline
\end{tabular}

Values/sentences in italics indicate the whole set/sum of the preceding rows. 


\section{Conclusions}

According to the LCA approach and considering the energy budget and GHG emission savings as the two main guiding criteria in the environmental assessment of bioenergy chains, there are clear evidences that the use of wheat straw for energy generation could be, in general terms, a good environmental choice.

More specifically, the establishing of an optimised wheat cropping system represents a relevant factor in order to obtain the best environmental performance, significantly abating both primary energy costs the GHG emissions.

There are several environmental improvements in adopting the innovative wheat cropping system (W2) based on a conservation tillage management coupled with a rotational cropping sequence with an herbage crop one year out of three. The main positive effects associated to $W 2$, as compared to $W 0$ and $W 1$, can be summarised schematically as follows:

- A reduced agricultural surface allocated to biomass collection is detected, due to the higher biomass productivity obtained in crop rotation conditions; this land surface reduction is about the $50 \%$ of the original surface assumed in $W 0$ and $W 1$. This means, indirectly, a lower pressure on the cultivated lands to fulfil compulsory targets on renewable energy supply.

- An overall reduced biomass transportation distance and, therefore, a lower environmental load (in terms of emission impact); this reduction is about the $65 \%$ as compared with $W 0$ and $W 1$.

- A large increase in the electrical generation efficiency (expressed in terms of energy output per energy input) is observed in $W 2$ with respect to $W 0$ and $W 1$. Similarly, a reduction in GHG emissions per unit of power produced (MWh) is also recorded. Overall, it can be inferred that the environmental performance of the optimised bioenergy value chain is greatly improved.

- Conservation tillage (i.e., no-till) significantly reduced mechanisation energy costs, due to diesel and lubricants lower consumptions, as compared with conventional tillage; this energy reduction was obviously converted in a lower GHG emission rate.

- Another relevant effect is the contribution of both no-tillage and partial straw retention in preserving soil organic carbon (SOC) and lowering $\mathrm{CO}_{2}$ emissions due to organic matter mineralisation. Considering the $W 2$ cropping system, over a 50 y-period, SOC never decreased below the initial $\mathrm{C}$ content as a concomitant effect of conservation tillage and partial herbage mulching.

- $\mathrm{N}_{2} \mathrm{O}$ released from the soil was reduced, quite considerably, as compared to straw left on the soil. Although easily understandable, this can be considered a new and unexpected result. The extent of annual $\mathrm{N}_{2} \mathrm{O}$ emissions was highly correlated with the total amount of cereal straw incorporated or left on the soil surface.

As clearly stated by Tilman et al. (2009), in a world seeking solutions to its energy, environmental, and food challenges, society cannot afford to miss out on the global greenhouse-gas emission reductions and the local environmental and societal benefits when biofuels are done right. However, society also cannot accept the undesirable impacts of biofuels done wrong. By selecting the best agricultural practices, energy from straw can be optimally coupled with grain productions, without detrimental effects on soil fertility and achieving the target to obtain both food and energy from renewable sources also effectively contributing to climate change mitigation. An improved and specifically tailored cropping system was designed and tested to obtain this optimal trade-off.

Table 4. Annual greenhouse gases emissions associated to the three wheat (grain and straw) value chains (W0,W1 and W2 as specified in the text). Functional unit of life cycle assessment: the first three-column set refers to the agricultural land surface unit (ha); the second one, to the electrical energy production unit (MWh).

\begin{tabular}{|c|c|c|c|c|c|c|}
\hline \multirow[t]{3}{*}{ Production stages } & \multicolumn{6}{|c|}{ GHG emissions } \\
\hline & \multicolumn{3}{|c|}{$\left(\mathrm{kg} \mathrm{CO}_{2} \mathrm{ha}^{-1} \mathbf{y}^{-1}\right)$} & \multicolumn{3}{|c|}{$\left(\mathrm{kg} \mathrm{CO} \mathrm{MWh}^{-1} \mathrm{y}^{-1}\right)$} \\
\hline & WU & $W I$ & W2 & WO & $W I$ & W2 \\
\hline \multicolumn{7}{|l|}{ Farm stage } \\
\hline Wheat cultivation & 1378.66 & 1378.66 & 1185.65 & 822.63 & 822.63 & 357.64 \\
\hline Delta due to the farming stage & - & - & -193.01 & - & - & -464.99 \\
\hline Straw chopping & 10.15 & - & - & 6.05 & - & - \\
\hline Change in soil carbon content & -374.00 & 154.00 & -102.67 & -223.16 & 91.89 & -30.97 \\
\hline $\mathrm{N}_{2} \mathrm{O}$ emission due to wheat cultivation & 451.90 & 263.64 & 409.28 & 269.64 & 157.31 & 123.46 \\
\hline Compensation of the straw fertilising value & - & 39.67 & 26.45 & - & 23.67 & 7.98 \\
\hline Compensation for reduced grain due to crop rotation & - & - & 395.22 & - & - & 119.21 \\
\hline Delta due to land use change & 88.04 & 457.32 & 728.28 & 52.53 & 272.88 & 219.68 \\
\hline \multicolumn{7}{|l|}{ Post farm stage } \\
\hline Straw baling & - & 17.50 & 35.00 & - & 10.44 & 10.56 \\
\hline Straw transportation & - & 5.88 & 2.16 & - & 3.51 & 0.65 \\
\hline Delta due to post farm stage & - & 23.38 & 37.16 & 0.00 & 13.95 & 11.21 \\
\hline Carbon debts (sum of the delta values) & 88.04 & 480.70 & 572.42 & 52.53 & 286.83 & -234.11 \\
\hline Carbon credits (fossil displacement) & - & -787.68 & -1558.15 & - & -470.00 & -470.00 \\
\hline Total balance & 88.04 & -306.98 & -985.73 & 52.53 & -183.17 & -704.11 \\
\hline Delta with respect to $W 0$ & - & -395.02 & -1073.77 & - & -235.71 & -756.64 \\
\hline
\end{tabular}

$\mathrm{GHG}$, greenhouse gases. Values/sentences in italics indicate the whole set/sum of the preceding rows. 


\section{References}

Alluvione F, Moretti B, Sacco D, Grignani C, 2011. EUE (Energy Use Efficiency) of cropping systems for a sustainable agriculture. Energy 36:4468-81.

Berndes G, Bird N, Cowie A, 2010. Bioenergy, land use change and climate change mitigation. IEA Bioenergy. Available from: http://task39.org/files/2013/05/Bioenergy-Land-Use-Change-andClimate-Change-Mitigation.pdf

BioGrace Project, 2014. Harmonised calculations of bioenergy greenhouse gas emissions in Europe. Projects funded by the Intelligent Energy Europe Programme, IEE/09/736/SI2.558249. Available from: http://www.biograce.net/

Brander M, Tipper R, Hutchison C, Davis G, 2009. Consequential and attributional approaches to LCA: a guide to policy makers with specific reference to greenhouse gas LCA of biofuels. Econometrica. Technical Paper TP-090403-A April. Available from: http://ecometrica.com/assets/approachesto_LCA3_technical.pdf

Butterbach-Bahl K, Baggs EM, Dannenmann M, Kiese R, ZechmeisterBoltenstern S, 2013. Nitrous oxide emissions from soils: how well do we understand the processes and their controls? Phil. Trans. R. Soc. B 368:20130122.

Cai Z, Laughlin RJ, Stevens RJ, 2001. Nitrous oxide and dinitrogen emissions from soil under different water regimes and straw amendment. Chemosphere 42:113-21.

Cherubini F, 2010. GHG balances of bioenergy systems - Overview of key steps in the production chain and methodological concerns. Renew. Ener. 35:1565-73.

Cherubini F, Bird ND, Cowie A, Jungmeier G, Schlamadinger B, WoessGallasch S. 2009. Energy- and GHG-based LCA of biofuel and bioenergy systems: Key issues, ranges and recommendations. 2009. Resour. Conserv. Recycl. 53:434-47.

Cherubini F, Ulgiati S, 2010. Crop residues as raw materials for biorefinery systems - A LCA case study. Appl. Ener. 87:47-57.

Cowie AL, Smith P, Dale J, 2006. Does soil carbon loss in biomass production systems negate the greenhouse benefits of bioenergy? Mitig. Adapt. Strat. Global Change 11:979-1002.

Dale BE, Bals BD, Kim S, Eranki P, 2010. Biofuels done right: land efficient animal feeds enable large environmental and energy benefits. Environ. Sci. Technol. 44:8385-9.

Davis SC, Anderson-Teixeira KJ, De Lucia EH, 2009. Life-cycle analysis and the ecology of biofuels. Trends Plant Sci. 14:140-6.

Davis SC, House JI, Diaz-Chavez RA, Molnar A, Valin H, DeLucia EH, 2011. How can land-use modelling tools inform bioenergy policies? Interface Focus 1:212-23.

Donatelli M., Stockle C, Ceotto E, Rinaldi M, 1997. Evaluation of CropSyst for cropping systems at two locations of northern and southern Italy. Eur. J. Agron. 6:35-45.

Fargione J, Hill J, Tilman D, Polasky S, Hawthorne P, 2008. Land clearing and the biofuel carbon debt. Science 319:1235-8.

Fritsche UR, Ralph EH, Sims REH, Monti A, 2010. Direct and indirect land-use competition issues for energy crops and their sustainable production - an overview. Biofuels Bioprod. Bioref. 4:692-704.

Gabrielle B, Gagnaire N, 2008. Life-cycle assessment of straw use in bio-ethanol production: a case study based on biophysical modelling. Biomass Bioener. 32:431-41.

Gan Y, Liang C, Campbell CA, Zentner RP, Lemke RL, Wang H, Yang C, 2012. Carbon footprint of spring wheat in response to fallow fre- quency and soil carbon changes over 25 years on the semiarid Canadian prairie. Eur. J. Agron. 43;175-84.

Garofalo P, Di Paolo E, Rinaldi M, 2009. Durum wheat (Triticum durum Desf.) in rotation with faba bean (Vicia faba var. minor L.): longterm simulation case study. Crop Pasture Sci. 60:240-50.

Gnansounou E, Dauriat A, Villegas J, Panichelli L, 2009. Life cycle assessment of biofuels: energy and greenhouse gas balances. Bioresour. Technol. 100:4919-30.

Gnansounou E, Panichelli L, Dauriat A, Villegas J, 2008. Accounting for indirect land-use changes in GHG balances of biofuels: review of current approaches. Working Paper REF. 437.101. École Polytechnique Fédérale de Lausanne, Switzerland.

Jungmeier G, Schwaiger H, 2000. Changing carbon storage pool in LCA of bioenergy - A static accounting approach for a dynamic effect. Life cycle assessment on forestry and forestry products. Cost Action E9, Brussel, Belgium, pp 101-15.

Keegan D, Kretschmer B, Elbersen B, Panoutsou C, 2013. Cascading use: a systematic approach to biomass beyond the energy sector. Biofuels Bioprod. Bioref. 7:193-206.

Kumar K, Goh KM, 2000. Crop residues and management practices effects on soil quality, soil nitrogen dynamics, crop yield, and nitrogen recovery. Adv. Agron. 68:197-316.

Lal R, 2008. Crop residues as soil amendments and feedstock for bioethanol production. Waste Manage. 28:747-58.

Meki MN, Kiniry JR, Behrman KD, Pawlowski MN, Crow SE, 2014. The role of simulation models in monitoring soil organic carbon storage and greenhouse gas mitigation potential in bioenergy cropping systems. In: C. do Rosario Vaz Morgado and V.P. Pechana Esteves (eds.), C02 sequestration and valorization. Rijeka: InTech; chapter 9. Available from: http://www.intechopen.com/books/co2-sequestration-and-valorization/the-role-of-simulation-models-in-monitoring-soil-organic-carbon-storage-and-greenhouse-gas-mitigatio

Monteleone M, 2015. Reshaping agriculture toward a transition to a post-fossil bioeconomy. In: M. Monteduro, P. Buongiorno, S. Di Benedetto, A. Isoni (eds.), Law and agroecology: a transdisciplinary dialogue. Berlin: Springer [in press].

Odegard I, Croezen H, Bergsma G, 2012. Cascading of biomass. 13 solutions for a sustainable bio-based economy. Delft, CE Delft. Available from: http://www.ce.nl/?go=home.downloadPub\&id= 1276\&file=CE_Delft_2665_Cascading_of_Biomass_def_13484900 86.pdf

Searchinger T, Heimlich R, Houghton RA, Dong F, Elobeid A, Fabiosa J, Tokgoz S, Hayes D, Yu T, 2008. Use of US croplands for biofuels increases greenhouse gases through emissions from land-use change. Science 319:1238-40.

Stöckle C, Donatelli M, Nelson R, 2003. CropSyst: a cropping system simulation model. Eur. J. Agron. 18:289-307.

Tilman D, Socolow R, Foley JA, Hill J, Larson E, Lynd L, Pacala S, Reilly J, Searchinger T, Somerville C, Williams R, 2009. Beneficial biofuels the food, energy, and environment trilemma. Science 325:270-1.

Venterea RT, Halvorson AD, Kitchen N, Liebig MA, Cavigelli MA, Del Grosso SJ, Motavalli PP, Nelson KA, Spokas KA, Singh BP, Stewart CE, Ranaivoson A, Strock J, Collins H, 2012. Challenges and opportunities for mitigating nitrous oxide emissions from fertilized cropping systems. Front. Ecol. Environ. 10:562-70.

Whittaker C, McManus M, 2012. The renewable energy directive and cereal residues. pp 2049-2057 in Proc. 20th European Biomass Conference and Exhibition, 18-22 June, Milan, Italy. 